\title{
Evaluating the effects of integrating trees into temperate arable systems on pest control and pollination
}

Article

Accepted Version

Creative Commons: Attribution-Noncommercial-No Derivative Works 4.0

Staton, T. ORCID: https://orcid.org/0000-0003-0597-0121, Walters, R. J., Smith, J. and Girling, R. D. (2019) Evaluating the effects of integrating trees into temperate arable systems on pest control and pollination. Agricultural Systems, 176. 102676. ISSN 0308-521X doi:

https://doi.org/10.1016/j.agsy.2019.102676 Available at https://centaur.reading.ac.uk/81517/

It is advisable to refer to the publisher's version if you intend to cite from the work. See Guidance on citing.

To link to this article DOI: http://dx.doi.org/10.1016/j.agsy.2019.102676

Publisher: Elsevier

All outputs in CentAUR are protected by Intellectual Property Rights law, including copyright law. Copyright and IPR is retained by the creators or other copyright holders. Terms and conditions for use of this material are defined in the End User Agreement. 


\section{CentAUR}

Central Archive at the University of Reading

Reading's research outputs online 


\section{Title page}

2

3 Title: Evaluating the effects of integrating trees into temperate arable systems on pest control

4 and pollination

5

6 Authors: Tom Staton ${ }^{\mathrm{a}, \star}$, Richard J Walters ${ }^{\mathrm{b}}$, Jo Smith ${ }^{\mathrm{c}}$, Robbie D Girling ${ }^{\mathrm{a}}$

7 a School of Agriculture, Policy and Development, University of Reading, Reading, UK

$8{ }^{b}$ Department of Biology, Lund University, Lund, Sweden

9 c Organic Research Centre, Elm Farm, Newbury, UK

10 * Corresponding author. E-mail address: t.staton@pgr.reading.ac.uk

11

12 Other author email addresses:

$13 \quad$ richard.walters@biol.lu.se

14 jo.s@organicresearchcentre.com

15 r.girling@reading.ac.uk

16

17 Declarations of interest: none

18 Submission date: $13 / 08 / 2019$

19 


\section{Abstract}

21 Agroforestry systems, which incorporate trees into agricultural land, could contribute to sustainable agricultural intensification as they have been shown to increase land productivity, biodiversity and some regulating ecosystem services. However, the effect of temperate agroforestry systems on pest control and pollination services has not been comprehensively reviewed, despite the importance of these services for sustainable intensification. We review and analyse the available evidence for silvoarable agroforestry systems, following which we propose a predictive framework for future research to explain the observed variation in results, based on ecological theory and evidence from analogous systems. Of the 12 studies included in our meta-analysis of natural enemies and pests, the observed increases in natural enemy abundance $(+24 \%)$ and decreases in arthropod herbivore/pest abundance $(-25 \%)$ in silvoarable systems were both significant, but molluscan pests were more abundant in silvoarable systems in the two available studies. Only three studies reported effects on pollinators, but all found higher abundance in silvoarable compared with arable systems. Measures of pest control or pollination service are scarce, but suggest stronger effect sizes. Our framework seeks to establish hypotheses for future research through an interpretation of our findings in the context of the wider literature, including landscape characteristics, silvoarable system design and management, system maturity, trophic interactions and experimental design. Our findings suggest that silvoarable systems can contribute to sustainable intensification by enhancing beneficial invertebrates and suppressing arthropod pests compared with arable, but future research should include measures of pest control and pollination and implications for productivity and economic value.

\section{Keywords: Agroforestry; Alley cropping; Sustainable agriculture; Conservation biological} control; Pollinators; Natural enemies 


\section{Introduction}

46 Global crop demand is rising rapidly, and is forecasted to increase by $100-110 \%$ from 2005 to

472050 (Tilman et al., 2011). The intensification of arable production in temperate regions has driven declines in biodiversity and associated ecosystem services, such as pest control and pollination (Bartomeus et al., 2014; Bianchi et al., 2006). This has in many cases led to a reliance on management techniques such as pesticide application, genetically modified crops and maintenance of managed honey bee colonies. The sustainability of such management practices is threatened by processes such as pesticide resistance (Sparks and Nauen, 2015), secondary pest outbreaks (Dutcher, 2007; Hill et al., 2017), depletion of non-renewable sources, environmental and human health risks associated with pesticides (Bernardes et al., 2015; Kim et al., 2017), and honey bee colony collapse or growth deficits (Aizen and Harder, 2009; Neumann and Carreck, 2010).

There is a strong and growing pressure to move towards more sustainable intensification of production, through harnessing natural processes to sustain productivity rather than relying on pesticides and managed pollinators (FAO, 2013; Power, 2010). One alternative tactic for reducing crop damage by pests is to enhance the effectiveness of their natural enemies, such as predators and parasitoids, by enhancing plant diversity and habitat complexity (Begg et al., 2017). This is the principle of conservation biological control (Barbosa, 1998). Similar arguments have been proposed to encourage wild pollinators (Kovács-Hostyánszki et al., 2017; Woodcock et al., 2016), which have the potential to increase the effectiveness of pollination in flowering crops and mitigate against potential honey bee losses (Garibaldi et al., 2013; Hoehn et al., 2008).

One possible solution to the need for sustainable intensification is agroforestry, essentially 'the incorporation of trees into farming systems' (Gordon et al., 2018). Agroforestry has been proposed as a 'win-win' opportunity for productivity and environmental protection (The

Woodland Trust, 2018). Although more typical of the tropics due to lower constraints posed 
by mechanisation and climatic factors such as light availability, there is growing interest in this land use system in temperate regions because of its potential contribution towards sustainable intensification (Newman and Gordon, 2018; Smith et al., 2012). For example, the 'establishment, regeneration or renovation of agroforestry systems' is promoted through the European Union's Common Agricultural Policy. Agroforestry is perceived as being beneficial for the environment and land stewardship, which are typically the main drivers for adoption (García de Jalón et al., 2018; Matthews et al., 1993).

Of particular interest in terms of the potential benefit from natural pest control and pollination is silvoarable agroforestry, which is the intercropping of trees or shrubs with arable crops (Fig. 1). Different methods of silvoarable production are practiced throughout northern temperate regions, sometimes being referred to by regional terminologies. These include tree-based intercropping and alley cropping systems in North America which typically use hardwoods for nut and timber production, and various agri-silviculture systems in the Himalayas (Newman and Gordon, 2018). Timber is typically the main tree product produced in silvoarable systems, although intercropping with fruit trees is widely practised in China (Chang et al., 2018) and its potential for a quick return on investment is encouraging uptake in the UK (Newman et al., 2018). Silvoarable systems are far scarcer in southern temperate regions, although research platforms have been established (Newman and Gordon, 2018). Temperate silvoarable systems have the potential to increase productivity compared with equivalent monocropped land, for example Land Equivalent Ratios of between 0.98 and 1.37 have been estimated over the full tree rotation (Graves et al., 2010; Gruenewald et al., 2007).

Several reviews and meta-analyses have demonstrated that temperate agroforestry systems generally enhance biodiversity and some ecosystem services compared with arable cropping (Smith et al., 2013; Stamps and Linit, 1997; Torralba et al., 2016; Tsonkova et al., 2012). However, the effects of silvoarable systems on pest control and pollination services remain poorly understood in temperate regions; all but two of 42 studies included in a recent metaanalysis of pest, disease and weed control were conducted in the tropics and sub-tropics, 


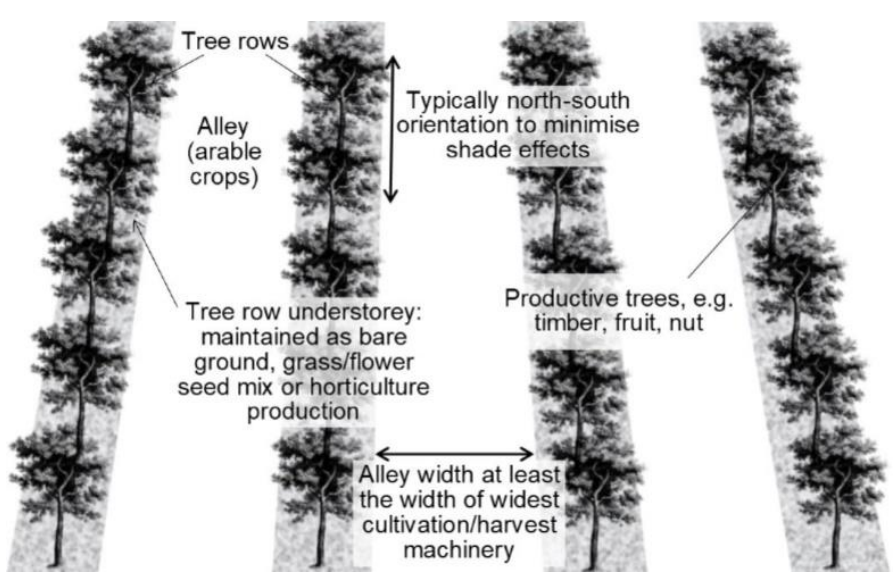

102

Fig. 1. Illustration of a typical silvoarable alley-cropping system.

The aims of this review are: 1) to collate and analyse studies of pollinators, pests and their natural enemies in temperate silvoarable systems, specifically in terms of their potential contribution to pest control and pollination ecosystem services; and 2) to develop a framework for future research to predict the factors which influence variation in results, with the aspiration of driving forward a unified research agenda.

\section{Methods}

110 Literature was sourced based on the following criteria (the selection process is summarised 111 at Supplementary Material 1):

1. A measure of abundance or activity density of invertebrate herbivores/pests, natural enemies or pollinators, and/or a measure of conservation biological control of animal pests and/or pollination were recorded;

2. Studies were undertaken in a temperate region, defined as latitude greater than $40^{\circ}$ 
north or south;

3. A silvoarable system, for this purpose defined as trees or shrubs incorporated into an arable field, was compared with an arable control, with the respective arable components comprising annual crops.

120 To minimise the risk of publication bias, we sourced both peer-reviewed and non-peer-

121 reviewed literature, including theses and reports.

122

\subsection{Data extraction}

123 A total of 19 datasets were identified (Supplementary Materials 2 and 3). We reviewed the characteristics of each study and the studied system(s), including sampling duration, alley width, system age, number of taxonomic orders studied and minimum distance between silvoarable and arable control plots. Capture or abundance data for natural enemies, pests (or

127 herbivores where pest species were not specified), pollinators, and pest control proxies was sourced from each dataset to analyse effect sizes. Where necessary, data was extracted from figures using GetData Graph Digitizer (version 2.26, http://getdata-graph-digitizer.com). Any data collected from tree rows was excluded where possible to provide a comparison of silvoarable alleys versus arable. Where pitfall trap data from tree rows could not be excluded, the study/site was omitted entirely from the analysis of effect sizes, because the structural complexity of vegetation in tree rows could reduce capture rates (Melbourne, 1999; Thomas

134 et al., 2006). One study was completely excluded and one study partially excluded (two of the three sites) on this basis (Supplementary Material 3).

\subsection{Meta-analysis for herbivores/pests and natural enemies}

137 To quantify the magnitude of effects for herbivores/pests and natural enemies, we calculated effect size as the log response ratio (Hedges et al., 1999) of mean functional group abundance

139 in the silvoarable system versus the arable control. Hence, the response variables were

140 herbivore/pest abundance and natural enemy abundance. The single explanatory variable 141 was presence or absence of a silvoarable system. 
142 Standard deviations could not be extracted for four of the 12 identified studies (Supplementary

143 Material 3), so were imputed based on their mean values (Lajeunesse, 2013). Three of the

144 four studies with missing standard deviations used pitfall trapping, therefore imputed standard 145 deviations were calculated based on the significant linear relationship between mean and 146 standard deviation for the two available pitfall trap studies with standard deviation data

147 (Griffiths et al., 1998; Phillips et al., 1994). The significance of effects for herbivore/pest and natural enemy abundances were analysed in a mixed-effects meta-analysis model, using the rma.mv function of the metaphor package version 2.1-0 (Viechtbauer, 2010) within $\mathrm{R}$ version

$150 \quad 3.5 .2$ (R Core Team, 2018). As multiple data points were extracted from some individual studies, study ID was included as a random effect. The results are reported as backtransformed values.

153 The imputation of standard deviations did not increase the risk of Type 1 errors, as effect sizes

154 were reduced and p-values increased, compared with models which omitted studies with missing standard deviations. Outliers and influential observations were quantified using Cook's distance. For the pest/herbivores model, Cook's distance for a slug abundance data point was 0.30 , compared with less than 0.05 for all other data points. Therefore, the results of a model excluding slug data (i.e. arthropods only) are also presented. For the natural enemies model, the data-point with the highest Cook's distance (0.13) was a negative effect size (i.e. lower abundance in the silvoarable plot than arable control) and was therefore retained to reduce the likelihood of a Type 1 error. Cook's distance was below 0.10 for all other data points. Publication bias was considered unlikely due to the inclusion of unpublished studies, but funnel plots were visually checked for symmetry. Heterogeneity, in the form of $P^{2}$ calculated from the models without random effects, ranged from $56 \%$ to $75 \%$, lower than the median of $85 \%$ reported for ecological meta-analyses (Senior et al., 2016).

\subsection{Review of other effect sizes}

167 Effect sizes were calculated from five studies which reported a proxy for pest control, such as 168 ratios of natural enemies to herbivores, pest mortality rates or pest parasitism rates, in a 
silvoarable system versus an arable control. Pollinator effect sizes were derived from three

170 studies which reported abundances in silvoarable systems and arable controls. To investigate

171 whether the functional group responses are highly influenced by any specific taxa, effect sizes

172 were also calculated for taxa which were included in three or more studies (Araneae,

173 Carabidae, Coccinellidae, Syrphidae and Aphididae). We calculated effect size as the mean

174 abundance (or for pest control proxies, the mortality/parasitism rate or ratio of natural enemies

175 to pests) in the silvoarable system, divided by the respective value for the arable control. Due

176 to the low number of available studies for these measures, pooled effect sizes were not 177 analysed. Finally, four studies reported some measure of crop damage or yield, which we 178 describe in the Results.

\subsection{Predictive framework}

180 Our findings were used to inform and construct a predictive framework for future research, which identifies a series of hypotheses to predict the factors which influence variation in the results. The components of the framework were selected based on a wider review of ecological theory and analogous systems, such as hedgerows, field margins, flower strips and beetle banks.

\section{Results}

\subsection{Characteristics of studies}

188 A total of 19 datasets were extracted from 17 studies undertaken in five countries, comprising 189 Canada, France, Turkey, UK and USA, with publication dates ranging from 1993 to 2015 190 (Supplementary Material 2). Data from the majority of the studies included in our analysis were taken from single sites over less than two years (Fig. 2a). There was a strong bias towards

192 systems with alley widths of around $12 \mathrm{~m}$ (Fig. 2b). Most of the studied systems were relatively 193 young in age, i.e. less than ten years since planting (Fig 2c). The majority of studies report on 
the abundances of three or fewer taxonomic orders, with only two studies reporting on seven or more orders (Fig. 2d). Where the minimum distance between the silvoarable and arable plots is specified, this is typically less than $50 \mathrm{~m}$ (Fig 2e, three outliers are not shown).
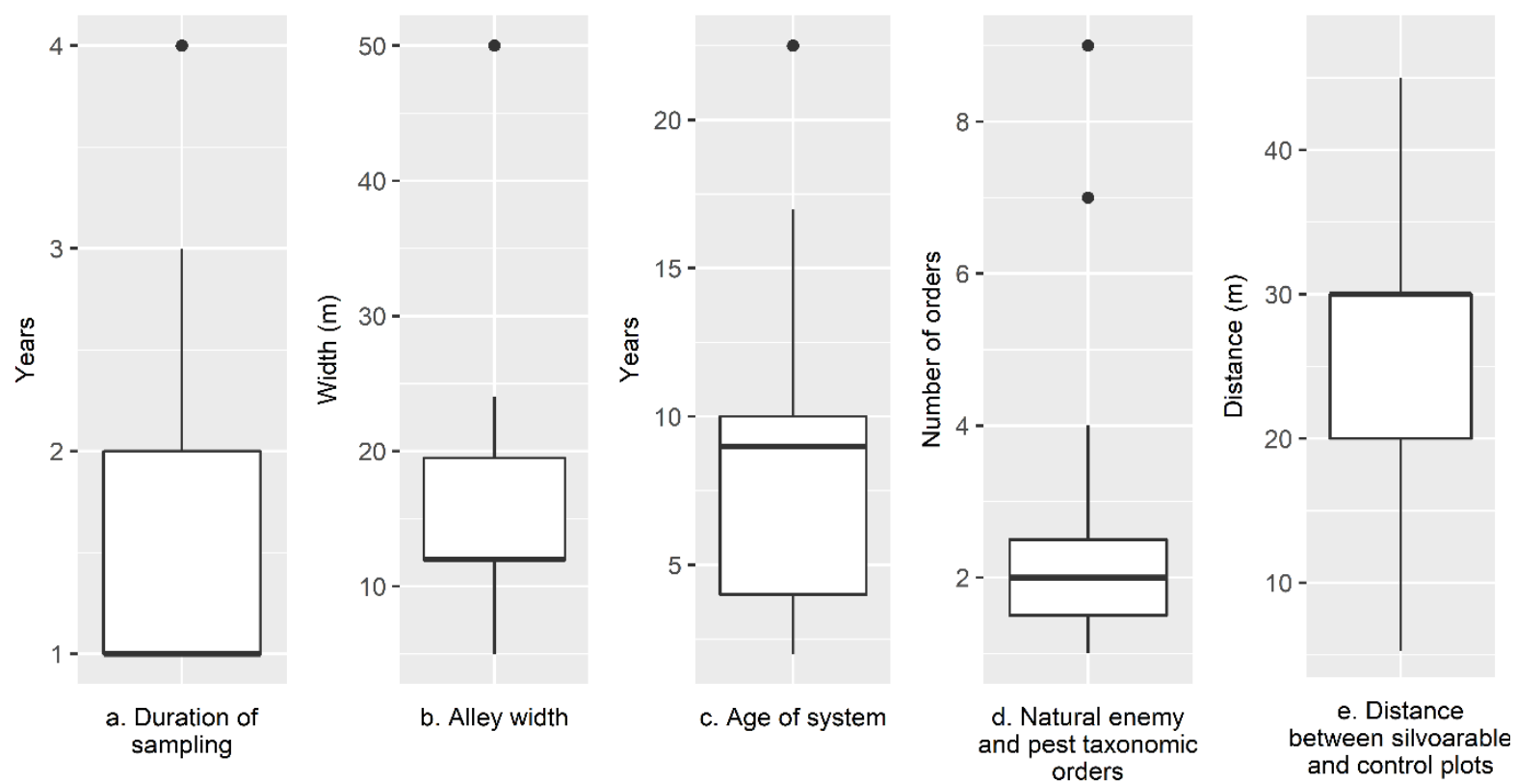

Fig. 2. Characteristics of studies of invertebrate pest control and pollination in temperate silvoarable systems, where the relevant information is specified (Supplementary Material 2). For studies of multiple sites, each site is represented individually. Multiple studies reporting on the same data are represented once collectively. Each 'box' represents the first and third quartiles, whilst the 'whiskers' extend to the largest/smallest value no further than $1.5^{*}$ inter-quartile range from the box. Three outliers are not plotted in Fig. $2 \mathrm{e}(130 \mathrm{~m}, 210 \mathrm{~m}$ and $270 \mathrm{~m})$, but are included in the calculations.

\subsection{Herbivores/pests and natural enemies: meta-analysis}

206 Invertebrate herbivore/pest abundances were lower in the silvoarable compared with arable systems, with a back-transformed mean effect size of 0.89 (Fig. 3), but this was not significant $(z=-0.650, p$-value $=0.516)$. However, the abundance of arthropod herbivores/pests was significantly lower in the silvoarable than arable systems $(z=-2.005, p$-value $=0.045)$, with a mean effect size of 0.75 (Fig. 3). This contrasts to slug abundance, which was higher in the silvoarable than arable systems, with effect sizes of 1.12 to 1.53 across the two studies. 
212 Natural enemy abundance was significantly higher in silvoarable compared with arable 213 systems $(z=2.528, p$-value $=0.011)$, with a mean effect size of 1.24 (Fig. 3). Only one of the 214 nine natural enemy effect sizes were less than one (Supplementary Material 3).

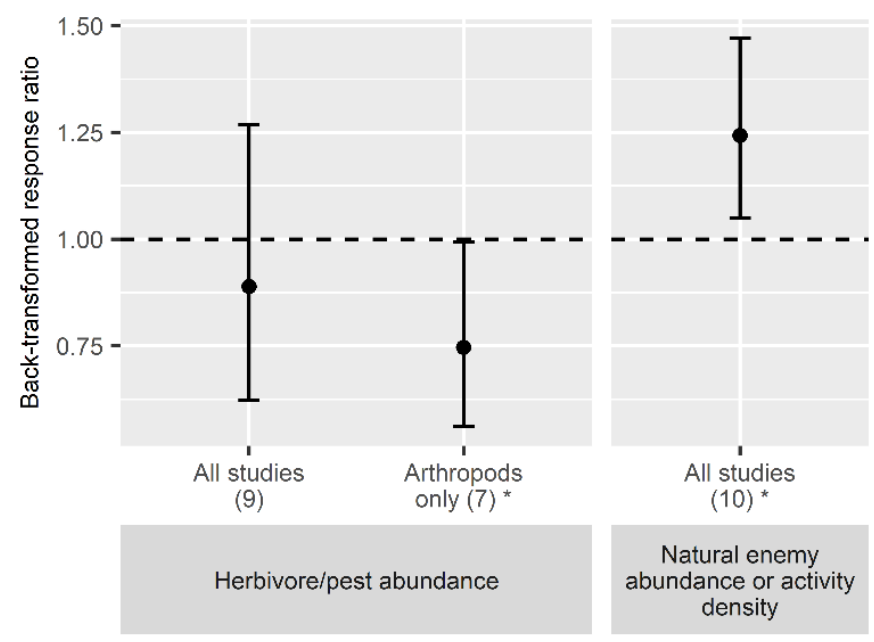

216 Fig. 3. Means and confidence intervals of the back-transformed response ratios of invertebrate

217 herbivore/pest and natural enemy abundance in silvoarable alleys (treatment) versus arable fields

218 (control). A response ratio of greater than 1 indicates a higher abundance in the silvoarable than the 219 arable system. Numbers in parentheses represent the number of studies and "*' denotes significance 220 ( $p$-value < 0.05). Data is provided in Supplementary Material 3.

221 Data from four sites reported in two studies were not included in the effect size analysis because pitfall trap data from tree rows and alleys could not be separated. In these studies, natural enemy activity was lower in the silvoarable system than the arable control at three of

224 the four sites, whilst the study which also sampled slugs found higher captures in the 225 silvoarable than the arable system at one site but lower captures in the silvoarable system at 226 the other site (Supplementary Material 3).

\subsection{Proxies for pest control}

228 One measure of pest control is the ratio of the number of natural enemies to herbivores/pests.

229 Two studies found a higher ratio in silvoarable versus arable systems (Table 1), which could be seen as a proxy for higher pest control. Three datasets included mortality or parasitism 
231 rates of pests, and all found consistently higher rates in silvoarable systems compared with

232 arable systems (Table 1), again suggesting a higher level of pest control.

\section{Table 1}

235 Summary of studies which reported proxies for pest control, i.e. ratios of airborne natural 236 enemies to herbivores or mortality/parasitism rates. Effect sizes are calculated as the 237 silvoarable ratio/rate divided by the respective arable control value.

\begin{tabular}{|c|c|c|c|c|c|c|c|}
\hline \multirow[t]{2}{*}{ Reference } & \multirow[t]{2}{*}{ Proxies for pest control } & \multicolumn{2}{|c|}{ Silvoarable } & \multicolumn{2}{|l|}{ Arable } & \multirow{2}{*}{$\begin{array}{l}\text { Effect } \\
\text { size }\end{array}$} & \multirow{2}{*}{$\begin{array}{l}\text { Tree row } \\
\text { data } \\
\text { excluded? }\end{array}$} \\
\hline & & Ratio & $\%$ & Ratio & $\%$ & & \\
\hline $\begin{array}{l}\text { Peng et al. } \\
\text { (1993) }\end{array}$ & $\begin{array}{l}\text { Ratio of airborne } \\
\text { natural enemies to } \\
\text { herbivores }\end{array}$ & 1.46 & - & 1.15 & - & 1.27 & Yes \\
\hline \multirow[t]{2}{*}{ Howell (2001) } & $\begin{array}{l}\text { Ratio of airborne } \\
\text { predators to herbivores }\end{array}$ & 1.79 & - & 1.37 & - & 1.31 & No \\
\hline & $\begin{array}{l}\text { Ratio of airborne } \\
\text { parasitoids to } \\
\text { herbivores }\end{array}$ & 2.94 & - & 1.08 & - & 2.72 & \\
\hline $\begin{array}{l}\text { Stamps et al. } \\
(2009 a)\end{array}$ & $\begin{array}{l}\text { Alfalfa weevil mortality } \\
\text { rate }\end{array}$ & - & 33.85 & - & 28.26 & 1.20 & $\begin{array}{l}\text { Yes (not } \\
\text { sampled) }\end{array}$ \\
\hline $\begin{array}{l}\text { Naeem et al. } \\
\text { (1997); Naeem } \\
\text { et al. (1994) }\end{array}$ & Aphid parasitism rate & - & 2.81 & - & 1.66 & 1.69 & Yes \\
\hline $\begin{array}{l}\text { Muhammad et } \\
\text { al. (2005) }\end{array}$ & Aphid parasitism rate & - & 12.8 & - & 7.6 & 1.68 & $\begin{array}{l}\text { Yes (not } \\
\text { sampled) }\end{array}$ \\
\hline
\end{tabular}

\subsection{Pollinator abundance}

240 Only three studies, in the UK and Canada, reported abundances of pollinating insects in 241 silvoarable systems and arable controls. Effect sizes ranged from 1.17 to 2.55 , indicating 
242 beneficial effects on pollinator populations in silvoarable systems compared with arable

243 controls (Table 2), but study replication was low. One study also reported higher California 244 Poppy phytometer seedset by a factor of 4.5 in agroforestry compared with arable systems 245 (Table 2).

\section{Table 2}

248 Effect sizes for studies which reported pollinator abundances or pollination service, calculated 249 as pollinator abundance or seedset in the silvoarable system divided by the respective value 250 in the arable control.

\begin{tabular}{llll}
\hline Reference & Taxa / measure of service & Effect size & Tree row data \\
& & & excluded? \\
\hline Peng et al. (1993) & Syrphidae, Bombus & 1.17 & Yes \\
Howell (2001) & Andrenidae, Apidae, Colletidae, Halictidae, & 1.72 & No \\
& Megachilidae, & 2.55 & No \\
Varah (2015): 2 & Syrphidae, Bombus (solitary bees excluded as & \\
sites & silvoarable data not separable from silvopasture & & No \\
& data) & & \\
& Seedset in Eschscholtzia californica phytometers & 4.5 & \\
& (across two silvoarable and one silvopasture site, & \\
& not separable)
\end{tabular}

\subsection{Taxon-specific effects}

254 The results were also analysed for aphids and four taxa of predators comprising Araneae, 255 Carabidae, Coccinellidae and Syrphidae. The effect sizes were highly variable, ranging below and above 1 in four of the five taxa analysed (Table 3). The only taxon represented by at least three studies which had consistently higher numbers in silvoarable systems compared with 
arable controls was hoverflies (Syrphidae).

259

260 Table 3

261 Effect sizes for five of the most commonly studied taxa in temperate silvoarable systems,

262 calculated as total or mean abundance in the silvoarable system divided by the respective

263 value in the arable control. Syrphidae only include species with predatory larvae.

\begin{tabular}{|c|c|c|c|c|c|}
\hline \multirow[t]{3}{*}{ Reference } & \multicolumn{5}{|c|}{ Effect size } \\
\hline & \multicolumn{4}{|c|}{ Natural enemies } & \multirow{2}{*}{$\begin{array}{l}\text { Herbivores / } \\
\text { pests } \\
\text { Aphidoidea }\end{array}$} \\
\hline & Araneae & Carabidae & Coccinellidae & Syrphidae & \\
\hline Peng et al. (1993) & $\begin{array}{l}1.35 \\
\text { (airborne) }\end{array}$ & - & 0.25 & 1.22 & $\begin{array}{l}1.77 \text { (all } \\
\text { species) }\end{array}$ \\
\hline Phillips et al. (1994) & - & 0.83 & - & 2.64 & - \\
\hline Peng and Sutton (1996) & 1.22 & 1.12 & 3.2 & - & \\
\hline Naeem et al. $(1994,1997)$ & - & - & - & - & $\begin{array}{l}0.53 \text { (one } \\
\text { species) }\end{array}$ \\
\hline Howell (2001) & $\begin{array}{l}0.95 \\
\text { (airborne) }\end{array}$ & $\begin{array}{l}9 \\
\text { (airborne) }\end{array}$ & 0.5 & 1.51 & $\begin{array}{l}0.26 \text { (all } \\
\text { species) }\end{array}$ \\
\hline Burgess et al. (2003): Leeds site & 0.65 & 0.73 & - & - & - \\
\hline Muhammad et al. (2005) & - & - & - & - & $\begin{array}{l}0.45 \text { (one } \\
\text { species) }\end{array}$ \\
\hline Smits et al. (2012) & - & - & - & - & $\begin{array}{l}1.01 \text { (three } \\
\text { species) }\end{array}$ \\
\hline Sharman (2015) & - & 1.54 & - & - & - \\
\hline
\end{tabular}

$2653.6 \quad$ Implications for crop damage and yield

266 Evidence of crop damage by invertebrate pests is very limited, and only two studies have

267 attempted to establish a link between pest control and yield of the arable component. Griffiths

268 et al. (1998) recorded higher slug damage to a pea crop in a UK silvoarable system compared 
with an arable control, with damage level positively correlated to slug captures. However, yield was not measured. In Turkey, Akbulut et al. (2003) observed a lower level of crop damage

271 from invertebrates in silvoarable plots, accompanied by higher yield of beans but lower yield

272 of maize, relative to arable. Other studies have simultaneously sampled cereal yields and invertebrates in silvoarable systems, finding lower silvoarable yields compared with arable in conventional systems (Burgess et al., 2003), and the opposite result in organic systems

275 (Varah, 2015), but disentangling the effect of pest control or pollination on yield from other 276 factors, notably tree-crop interactions such as shade, is problematic.

\section{Discussion}

\subsection{Effects of temperate silvoarable systems on pest control and pollination}

\subsubsection{Invertebrate herbivores / pests}

281 Our analysis demonstrates a reduced arthropod herbivore abundance in silvoarable alleys than in arable control conditions. This is consistent with the resource concentration hypothesis, which predicts that specialist herbivores, i.e. those with a narrow host range, should be less abundant in a more diverse system than a monoculture of just its host plant, due to the masking of host chemical cues (Root, 1973). This hypothesis does not however extend to generalist pests such as slugs, for which we find evidence of higher abundance in silvoarable systems relative to arable controls, although these results were derived from only two sites. Similar effects have been reported in and adjacent to flower-rich field margins (Eggenschwiler et al., 2013; Frank, 1998), which suggests that areas which provide a refuge from tillage could boost slug populations.

\subsubsection{Natural enemies}

292 The findings indicate the natural enemies of pests are more abundant in silvoarable alleys compared with arable systems, although there are no clear differences in responses among 
natural enemy taxa. The benefit to natural enemies could be explained by the resources

295 provided by silvoarable systems. For example, undisturbed tree rows could provide 296 overwintering refugia, which have been shown to be important for the maintenance of ground297 based natural enemy populations in other systems (Landis et al., 2000; Öberg et al., 2008; 298 Varchola and Dunn, 2001). Silvoarable systems could also enhance fine-scale complexity which has been shown to benefit parasitoids (Chaplin-Kramer et al., 2011; Thies et al., 2005), whilst tree rows could provide alternative food sources often required by this functional group (Dyer and Landis, 1996; Murphy et al., 1998; Pfannenstiel et al., 2010).

\subsubsection{Pollinators}

303 Although study replication was low, the observed increase in pollinator abundance in silvoarable systems compared with arable controls is consistent with the demonstrated benefits of flowering strips and hedgerows (Garratt et al., 2017; Morandin and Kremen, 2013; Nicholls and Altieri, 2013). This could be explained by the sheltered microclimate in silvoarable systems, in addition to the potential for flowering resources in silvoarable tree rows, including the understorey. The uncultivated tree rows could also provide nesting opportunities for pollinators, as demonstrated by a previous modelling exercise which predicted that nesting bee abundance would be increased by adopting silvoarable systems at a landscape scale

311 (Graham and Nassauer, 2017).

\subsubsection{Magnitude of effects}

313 Our reported mean effect sizes of 1.24 and 0.75 on natural enemy and arthropod

314 herbivore/pest abundances respectively are similar to those reported from meta-analyses of 315 other field scale enhancements such as polycultures, orchard vegetation management and 316 global (predominantly tropical) agroforestry, which range from 1.11 to 1.50 for natural 317 enemies, and 0.68 to 0.78 for pests (Iverson et al., 2014; Pumariño et al., 2015; Winter et al., 2018). These effect sizes are, however, considerably smaller than those typically observed for complex landscapes with a high proportion of non-crop habitats where, taking natural enemy abundance as an example, the majority of studies report effect sizes of at least 2 compared 
321 with simple large-scale landscapes (Bianchi et al., 2006).

322

323

324

325

326

327

328

\subsubsection{Effects on pest control and pollination services}

We find limited evidence of effects on pest control or pollination services, although there is some evidence for higher ratios of airborne natural enemies to herbivores, pest mortality and parasitism rates in silvoarable compared with arable systems. This limited evidence does however support the expectations of Stamps and Linit (1997), who recognised the theoretical potential for agroforestry systems to benefit pest control through plant diversification. Evidence for corresponding effects on crop damage or yield is scarcer still, with contradictory evidence, whilst evidence for pollination service is limited to a finding of higher California Poppy seedset in silvoarable compared with arable systems across two sites (Varah, 2015). The economic implications of pest control and pollination in silvoarable systems have yet to be assessed.

\subsection{A proposed framework for future research}

Agroforestry research in general is constrained by the suitability of appropriately scaled field sites designed for experimental vigour with proper controls (Stamps and Linit, 1999), which poses unique challenges to evaluating the factors which influence variation in effects. We therefore propose a framework to predict how these factors influence the observed abundances of natural enemies, pests and pollinators in temperate silvoarable systems (Fig. 4). For each identified factor which could influence variation, we refer to evidence from the studies included in our analysis and, as these are limited, ecological theory and evidence from analogous systems, where available, to form a series of hypotheses which can be tested by future research. 


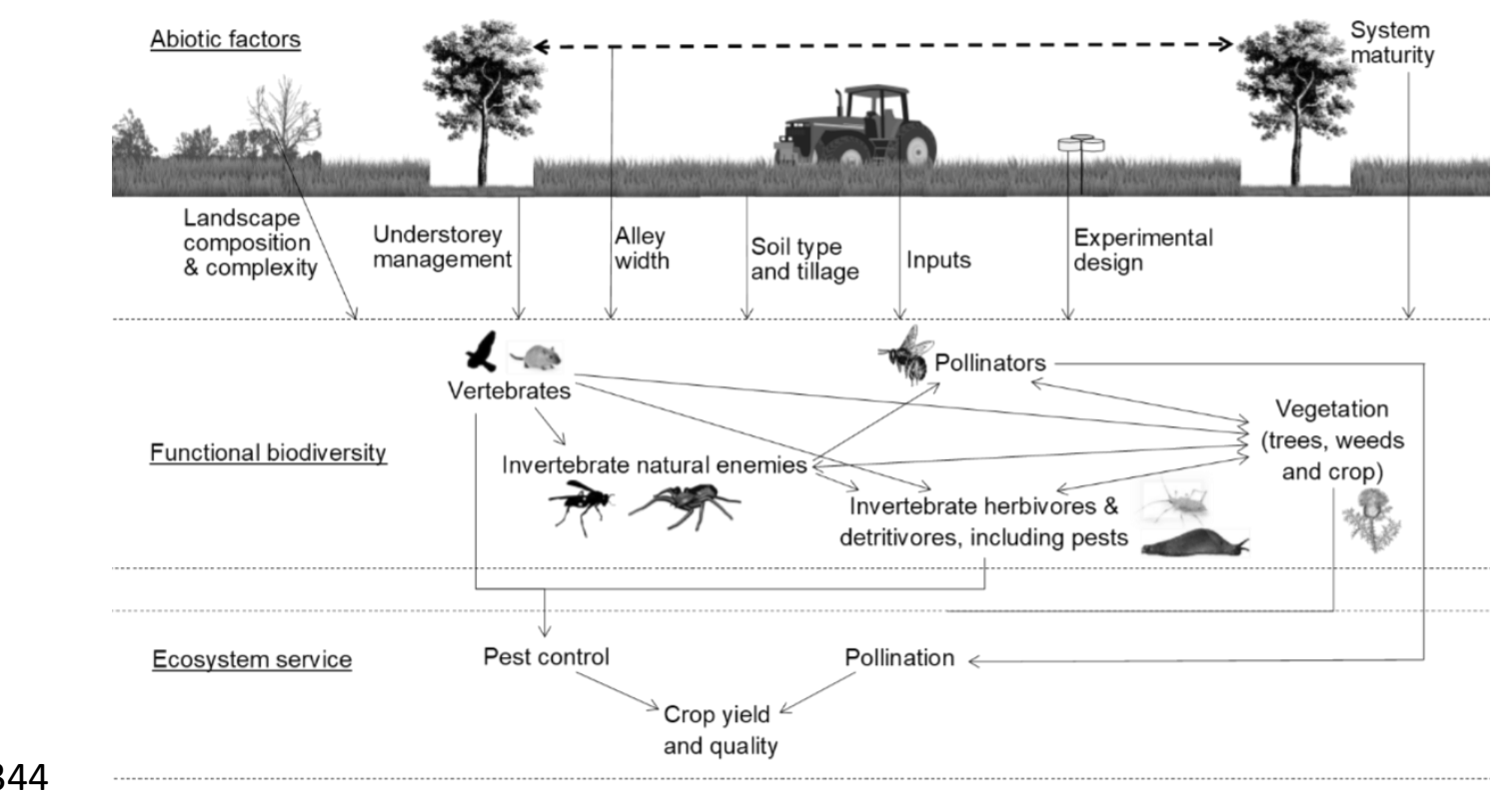

345 Fig. 4. Illustrative summary of the key factors predicted to influence functional biodiversity in temperate 346 silvoarable systems, the major interactions between functional groups and their contribution to pest 347 control and pollination.

\subsubsection{Soil type and tillage}

350 Although direct evidence is lacking, soil type could be critical in the outcome of pest control based on the evidence for slug problems in silvoarable systems. For example, a major slug pest, Deroceras reticulatum, favours fine-textured soils with high moisture content (Ondina et al., 2004), suggesting that silvoarable systems on such soil types could be prone to higher

354 pest damage. Further research could investigate whether adapting soil cultivation in silvoarable systems could help mitigate this damage, for example, by modifying tillage depth, timing and/or frequency (Roger-Estrade et al., 2010).

\subsubsection{Inputs}

358 Our findings of enhanced natural enemy activity and reduced pest pressure in silvoarable 359 alleys compared with arable controls suggest that pesticide inputs in non-organic systems 360 could potentially be reduced without compromising productivity, as demonstrated for 361 hedgerow restoration (Morandin et al., 2016). Furthermore, an enhanced level of pest control 
362 in organic silvoarable systems compared with arable controls could reduce crop loss to pests.

363 These hypotheses warrant further investigation.

364

365

366

367

368

369

\subsubsection{Alley width}

Alley width is typically constrained by the size of machinery in temperate regions. Although there is a strong bias in the literature towards systems with alley widths of around $12 \mathrm{~m}$ (Fig. $2 b)$, three studies included in our analysis found that tree rows or the edges of crop alleys support greater abundances of natural enemies and lower pest abundances than the centre of crop alleys (Peng et al., 1993; Phillips et al., 1994; Rekany, 2015). Furthermore, stronger distribution patterns of predators have been observed in $50 \mathrm{~m}$ crop alleys compared with $24 \mathrm{~m}$ alleys (Rekany, 2015). This broadly corresponds to studies of woody field boundaries, which find highest abundances of natural enemies and pollinators at around 2 to $10 \mathrm{~m}$ from the boundary, before rapidly declining (Lewis, 1969; Morandin et al., 2014). Future research could therefore test whether narrow alley widths have the greatest benefit on pollination and natural enemy activity.

\subsubsection{Understorey management}

Two of the studies included in our analysis compared vegetated understoreys with chemically weeded understoreys. A study of aphid natural enemies found no effect between treatments, possibly because the vegetated treatment did not properly establish (Smits et al., 2012). However, Burgess et al. (2003) found fewer slugs and more spiders in alleys adjacent to vegetated versus bare understoreys, suggesting that understorey vegetation promotes pest control, although there was little difference in carabid beetle abundance between treatments. Nevertheless, management of silvoarable tree rows to promote tussock-forming grasses could replicate the benefits of beetle banks (Collins et al., 2003), which is worthy of further investigation.

In addition, evidence from flower strips shows that mixes rich in pollen and nectar are most beneficial to pollinators, whilst natural enemies appear to be less strongly associated with 
vegetation type (reviewed in Haaland et al. (2011)). Nevertheless, flower strips designed to

389 benefit natural enemies of wheat pests have been successful in reducing pest pressure

390 (Tschumi et al., 2015). A similar tailored approach could be investigated in silvoarable 391 systems.

\subsubsection{Maturity}

393 The longest-running study in our analysis found that the slug population increased over the course of four years in a young silvoarable system compared with a control plot (Griffiths et al., 1998), whilst the abundance and/or diversity of birds and small mammals has also been shown to increase with system maturity (Gibbs et al., 2016; Klaa et al., 2005). Conversely, the abundance and diversity of epigeal invertebrate predators showed no significant response to field margin and hedgerow age in the UK, suggesting rapid colonisation, although some species were more closely associated with mature habitat (Pywell et al., 2005). We recommend that this could be investigated through long-term studies of invertebrate communities in silvoarable systems.

\subsubsection{Vegetation}

403 Two of the studies included in our analysis considered diversity and abundance of vascular plants in silvoarable versus arable systems, finding higher plant species richness in silvoarable alleys (Varah, 2015) and greater cover of non-crop plants, especially adjacent to vegetated understoreys, possibly due to seed-spread during cutting (Burgess et al., 2003). In contrast, lower numbers of weeds were found in a silvoarable system in France relative to an arable control early in the season, despite a higher species richness in the silvoarable system

409 (Meziere et al., 2016). This contrast among studies could be explained by the differing abilities of weed species to ingress from perennial habitats (Marshall, 2004). Therefore, we would predict that weed problems in silvoarable systems will be highly context-dependent. Weed cover could also provide a mechanism for the observed benefits on natural enemies and pollinators in silvoarable systems, as demonstrated by a positive association of carabid beetle

414 activity with weed cover in one of the studies in our analysis (Sharman, 2015). 
415 The choice of tree species could influence micro-climatic conditions and provide resources

416 such as nectar for functional groups. Studies of hedgerows and agroecosystems generally

417 show that plant diversity enhances natural pest control and pollination services (Garratt et al.,

418 2017; Isbell et al., 2017; Letourneau et al., 2011), and we would predict this to apply to 419 silvoarable systems. On the contrary however, interplanting shrubs within apple tree rows did 420 not influence pest or natural enemy communities in one silvoarable system (Kranz et al., 421 2018), although confirmatory evidence is needed from other systems to improve our 422 understanding of the influence of tree species and diversity on pest control and pollination.

423 The choice of arable crop may also influence results, for example, the study with the weakest effect size for pollinators was of a pea crop, possibly because of the attractant effect of the mass-flowering resource in the control plot compared with studies based on cereal crops.

426 Long-term and/or multiple-site studies would further test this hypothesis.

\subsubsection{Trophic interactions among fauna}

428 In general, the efficacy of conservation biological control is dependent on synergistic or 429 antagonistic interactions between natural enemies (Straub et al., 2008; Thies et al., 2011), 430 whilst predation of pollinators could reduce fruit set (Dukas, 2005). Few studies in our analysis 431 considered these interactions, although positive correlations have been demonstrated 432 between spiders and carabid beetles in a North American silvoarable system, suggesting 433 limited interference (Stamps et al., 2009b).

Interactions between vertebrates and invertebrates could also play a role in pest control and pollination, particularly given the potential benefits of silvoarable systems on vertebrate populations. A literature search on vertebrates in temperate silvoarable systems yielded four additional studies (Supplementary Material 2), which reported increased abundance and/or species richness of small mammals (Klaa et al., 2005; Wright, 1994), bats (Disca, 2003) and birds (Gibbs et al., 2016; Williams et al., 1995). Vertebrates could benefit pest control through 
441 vertebrates could directly cause pest problems, for example crop damage arising from roe

442 deer, rabbits, wild boar and pigeons have been anecdotally reported in silvoarable systems

443 (Gosme, 2014; Newman et al., 2018; Smith et al., 2016). Vertebrates could also disrupt natural 444 enemy functionality (Martin et al., 2013), for example, an apparent increase in rats correlated 445 with a substantial decrease in carabid beetle abundance in a silvoarable system (Stamps et 446 al., 2009b). Interactions are therefore an important avenue for further research given their 447 implications for pest control and potentially pollination.

\subsubsection{Landscape composition and complexity}

449 Two of the studies included in our analysis identified that proximity to treed landscape features 450 (forestry plots or boundary hedgerows) outside of the silvoarable system influenced their 451 results, benefitting pest parasitism and pollinator abundance respectively (Muhammad et al., 452 2005; Varah, 2015). The study with the second-lowest calculated effect size of natural enemy abundance noted that the diversity of the surrounding landscape may have masked any

454 benefit of the silvoarable system (Smits et al., 2012), whilst a well-studied system in an 455 intensive agricultural landscape had relatively strong effect sizes for natural enemies and 456 pollinators (Rekany, 2015; Sharman, 2015; Varah, 2015). This is supported by landscapescale studies of pest control and pollination, which suggest that functionality is high in diverse landscapes (Holzschuh et al., 2007), such that field-scale enhancements are more likely to be effective in simple landscapes, defined as 1-20\% of non-crop habitat (Tscharntke et al., 2005).

460 Although this hypothesis would be difficult to vigorously test in silvoarable systems, a 461 standardised experimental design across a network of sites with similar characteristics but 462 differing landscape context would help to predict those landscapes in which silvoarable systems would be most effective in terms of natural pest control and pollination.

\subsubsection{Experimental design}

Our results show that effect sizes in silvoarable systems tend to be relatively small compared with landscape-scale studies, and so experiments should be designed to have sufficient power to detect effect sizes of 10 to $30 \%$ (Fig. 3). Experimental design and analysis should take 
468 limitations of survey techniques into account, for example, the inclusion of pitfall trap data

469 collected from tree rows with complex understoreys in comparisons between silvoarable and 470 arable systems could bias results against silvoarable systems (Thomas et al., 2006), as

471 indicated by our analysis (Supplementary Material 3). Differences between the silvoarable and 472 arable control plots could also influence results, particularly differences in historical land use, 473 environmental conditions (including soil type), crop selection, management, proximity to 474 landscape features and proximity between treatment and control plots.

\subsection{Study limitations}

477 Our analysis of pests, natural enemies and pollinators focusses on invertebrates, as other 478 taxa have been scarcely studied in temperate silvoarable systems and predicting their net 479 effect on pest control and pollination is often more complex than for most invertebrates. 480 Nevertheless, we consider plants and vertebrates and their potential implications for pest 481 control and pollination in our predictive framework above.

482 Pests of the arable crop component of silvoarable systems are the focus of the study, rather 483 than pests of the tree component which have been scarcely studied. Nevertheless, there is 484 some evidence that aphid densities are lower in silvoarable tree rows than in forestry controls 485 (Naeem and Compton, 2000; Naeem et al., 1997). Two studies have referred to pest damage 486 in silvoarable apple trees compared with orchards, although results are inconclusive and appear to vary according to pest taxa and fruit stage (Kranz et al., 2018; Smith et al., 2014).

488 Our analysis pools together numbers of captures/observations for different taxa recorded in each study, therefore, numerically abundant species are well represented in effect sizes compared with less abundant species, regardless of their body size or effect on pest control or pollination. Given that small sized carabid beetles were trapped at higher abundance in

492 silvoarable compared with arable systems, in contrast to large generalist species (Rekany, 493 2015), accounting for body size could reduce effect sizes, although the situation is complex 
494 as larger carabid species could also predate smaller carabids (e.g. Prasad and Snyder 495 (2006)), thereby antagonising pest control.

496 The analysis of pooled numbers of captures/observations does not take diversity into account, 497 as only two of the studies report on diversity of functional groups, finding significantly higher 498 diversities of invertebrate predators, herbivores and parasitic Hymenoptera in silvoarable 499 relative to arable systems (Howell, 2001; Stamps et al., 2002).

500 Whilst our analysis goes some way to comparing pests, natural enemies and pollinators in

501 silvoarable systems compared with arable, more research is needed to quantify subsequent 502 effects on pest control and pollination service outcome.

\section{Conclusion}

504 We find evidence for significantly enhanced natural enemy populations and significantly supressed arthropod herbivore populations in silvoarable systems, but molluscan pests were more numerous in the two available studies, compared with arable. Pollinators were also more

507 abundant in silvoarable than arable systems, but study replication was low. This suggests a higher efficacy of pollination and natural pest control in silvoarable crop alleys compared with arable systems, although crop damage from slugs could cause problems on some farms. Our findings therefore provide further support for the role of silvoarable systems in sustainable intensification, in conjunction with the demonstrated benefits to other ecosystem services (e.g.

512 Smith et al. (2013); Torralba et al. (2016); Tsonkova et al. (2012)). Nevertheless, further well-

513 replicated empirical research or modelling studies are required to test our predictive framework

514 of the factors which influence pests, natural enemies and pollinators in silvoarable systems,

515 in addition to measures of pest control and pollination, and their implications for productivity, economic output and resilience. 


\section{Acknowledgements}

518 This work was financially supported by the Natural Environment Research Council's (NERC)

519 Centre for Doctoral Training in Quantitative and Modelling Skills in Ecology and Evolution

520 (QMEE). The wider project is in collaboration with Helen Chesshire at the Woodland Trust.

521 We are grateful to Fiona Gierer and Dr Tom Breeze for comments and suggestions on the

522 manuscript, and to three anonymous reviewers for their detailed and constructive comments.

\section{Supplementary Material}

524 Supplementary Material 1. Flow diagram for literature selection based on PRISMA.

525 Supplementary Material 2. Attributes of reviewed literature.

526 Supplementary Material 3. Effect sizes of natural enemy and pest/herbivore abundances or

527 activity densities (used to inform Fig. 3).

\section{References}

529 Aizen, M.A., Harder, L.D., 2009. The global stock of domesticated honey bees is growing 530 slower than agricultural demand for pollination. Curr. Biol. 19, 915-918.

531 Akbulut, S., Keten, A., Stamps, W.T., 2003. Effect of alley cropping on crops and arthropod diversity in Duzce, Turkey. J. Agron. Crop Sci. 189, 261-269.

533 Barbosa, P.A., 1998. Conservation Biological Control. Academic Press, San Diego,

534 California, USA.

535 Bartomeus, I., Potts, S.G., Steffan-Dewenter, I., Vaissiere, B.E., Woyciechowski, M.,

536 Krewenka, K.M., Tscheulin, T., Roberts, S.P., Szentgyörgyi, H., Westphal, C., 2014.

537 Contribution of insect pollinators to crop yield and quality varies with agricultural

538 intensification. PeerJ 2, e328.

539 Begg, G.S., Cook, S.M., Dye, R., Ferrante, M., Franck, P., Lavigne, C., Lövei, G.L.,

540 Mansion-Vaquie, A., Pell, J.K., Petit, S., 2017. A functional overview of conservation

541 biological control. Crop Protect. 97, 145-158.

542 Bernardes, M.F.F., Pazin, M., Pereira, L.C., Dorta, D.J., 2015. Impact of Pesticides on 543 Environmental and Human Health, in: Andreazza, A.C. (Ed.), Toxicology Studies - Cells, 544 Drugs and Environment. Intech Europe, Rijeka, Croatia, pp. 195-233.

545 Bianchi, F.J., Booij, C., Tscharntke, T., 2006. Sustainable pest regulation in agricultural

546 landscapes: a review on landscape composition, biodiversity and natural pest control. Proc.

547 R. Soc. Lond., Ser. B: Biol. Sci. 273, 1715-1727. 
548 Burgess, P., Incoll, L., Hart, B., Beaton, A., Piper, R., Seymour, I., Reynolds, F., Wright, C., 549 Pilbeam, D., Graves, A., 2003. The impact of silvoarable agroforestry with poplar on farm

550 profitability and biological diversity. Final Report to DEFRA, Cranfield University,

551 Bedfordshire, UK.

552 Chang, S.X., Wang, W., Wu, Y., Zhu, Z., Peng, X., 2018. Temperate Agroforestry in China,

553 in: Gordon, A.M., Newman, S.M., Coleman, B. (Eds.), Temperate Agroforestry Systems, 2nd 554 ed. CABI, Wallingford, UK, pp. 173-194.

555 Chaplin-Kramer, R., O’Rourke, M.E., Blitzer, E.J., Kremen, C., 2011. A meta-analysis of crop 556 pest and natural enemy response to landscape complexity. Ecol. Lett. 14, 922-932.

Collins, K., Boatman, N., Wilcox, A., Holland, J., 2003. Effects of different grass treatments used to create overwintering habitat for predatory arthropods on arable farmland. Agric., Ecosyst. Environ. 96, 59-67.

560 Disca, T., 2003. Impact des pratiques agroforestières sur l'évolution de la

561

562

563

564

565

566

567

568

569

570

571

572

573

574

575

576

577

578

579

580

581

582

583

584

585

biodiversité - Etude des chiroptères, Programme Intégré de Recherches en Agroforesterie à ResTinclières (PIRAT)- Rapport d'activité 2003, pp. 94-104.

Dukas, R., 2005. Bumble bee predators reduce pollinator density and plant fitness. Ecology 86, 1401-1406.

Dutcher, J.D., 2007. A review of resurgence and replacement causing pest outbreaks in IPM, in: Ciancio, A., Mukerji, K.G. (Eds.), General concepts in integrated pest and disease management. Springer, Dordrecht, pp. 27-43.

Dyer, L.E., Landis, D.A., 1996. Effects of habitat, temperature, and sugar availability on longevity of Eriborus terebrans (Hymenoptera: Ichneumonidae). Environ. Entomol. 25, 11921201.

Eggenschwiler, L., Speiser, B., Bosshard, A., Jacot, K., 2013. Improved field margins highly increase slug activity in Switzerland. Agron. Sustain. Dev. 33, 349-354.

FAO, 2013. Policy Support Guidelines for the Promotion of Sustainable Production Intensification and Ecosystem Services. Plant Production and Protection Division, Food and Agriculture Organization of the United Nations, Rome.

Frank, T., 1998. Slug damage and numbers of the slug pests, Arion lusitanicus and Deroceras reticulatum, in oilseed rape grown beside sown wildflower strips. Agric., Ecosyst. Environ. 67, 67-78.

García de Jalón, S., Burgess, P.J., Graves, A., Moreno, G., McAdam, J., Pottier, E., Novak, S., Bondesan, V., Mosquera-Losada, R., Crous-Durán, J., 2018. How is agroforestry perceived in Europe? An assessment of positive and negative aspects by stakeholders. Agrofor. Syst. 92, 829-848.

Garibaldi, L.A., Steffan-Dewenter, I., Winfree, R., Aizen, M.A., Bommarco, R., Cunningham, S.A., Kremen, C., Carvalheiro, L.G., Harder, L.D., Afik, O., 2013. Wild pollinators enhance fruit set of crops regardless of honey bee abundance. Science 339, 1608-1611.

Garratt, M.P., Senapathi, D., Coston, D.J., Mortimer, S.R., Potts, S.G., 2017. The benefits of hedgerows for pollinators and natural enemies depends on hedge quality and landscape context. Agric., Ecosyst. Environ. 247, 363-370.

Gibbs, S., Koblents, H., Coleman, B., Gordon, A., Thevathasan, N., Wiliams, P., 2016. Avian diversity in a temperate tree-based intercropping system from inception to now. Agrofor. 
Gordon, A., Newman, S., Coleman, B., Thevathasan, N., 2018. Temperate agroforestry: an overview, in: Gordon, A., Newman, S., Coleman, B. (Eds.), Temperate Agroforestry Systems, 2nd ed. CABI, Wallingford, UK, pp. 1-6.

Gosme, M., 2014. Initial Stakeholder Meeting Report: Mediterranean Silvoarable Systems in France. AGFORWARD, France.

597 Graham, J., Nassauer, J., 2017. Wild bee abundance in temperate agroforestry landscapes:

598 Assessing effects of alley crop composition, landscape configuration, and agroforestry area.

599 Agrofor. Syst. https://doi.org/10.1007/s10457-017-0179-1.

600 Graves, A.R., Burgess, P.J., Palma, J., Keesman, K., van der Werf, W., Dupraz, C., van

601 Keulen, H., Herzog, F., Mayus, M., 2010. Implementation and calibration of the parameter-

602 sparse Yield-SAFE model to predict production and land equivalent ratio in mixed tree and

603 crop systems under two contrasting production situations in Europe. Ecol. Model. 221, 1744-

6041756.

605 Griffiths, J., Phillips, D., Compton, S., Wright, C., Incoll, L., 1998. Responses of slug

606 numbers and slug damage to crops in a silvoarable agroforestry landscape. J. Appl. Ecol.

$60735,252-260$.

608 Gruenewald, H., Brandt, B.K., Schneider, B.U., Bens, O., Kendzia, G., Hüttl, R.F., 2007.

609 Agroforestry systems for the production of woody biomass for energy transformation

610 purposes. Ecol. Eng. 29, 319-328.

611 Haaland, C., Naisbit, R.E., Bersier, L.-F., 2011. Sown wildflower strips for insect

612 conservation: a review. Insect Conserv. Divers. 4, 60-80.

613 Hedges, L.V., Gurevitch, J., Curtis, P.S., 1999. The meta-analysis of response ratios in

614 experimental ecology. Ecology 80, 1150-1156.

615 Hill, M.P., Macfadyen, S., Nash, M.A., 2017. Broad spectrum pesticide application alters 616 natural enemy communities and may facilitate secondary pest outbreaks. PeerJ 5, 24.

617 Hoehn, P., Tscharntke, T., Tylianakis, J.M., Steffan-Dewenter, I., 2008. Functional group

618 diversity of bee pollinators increases crop yield. Proc. R. Soc. Lond., Ser. B: Biol. Sci. 275, 619 2283-2291.

620 Holzschuh, A., Steffan-Dewenter, I., Kleijn, D., Tscharntke, T., 2007. Diversity of flower-

621 visiting bees in cereal fields: effects of farming system, landscape composition and regional

622 context. J. Appl. Ecol. 44, 41-49.

623 Howell, H.D., 2001. Comparison of arthropod abundance and diversity in intercropping 624 agroforestry and corn monoculture systems in southern Ontario. MSc thesis. University of 625 Toronto, Canada.

626 Isbell, F., Adler, P.R., Eisenhauer, N., Fornara, D., Kimmel, K., Kremen, C., Letourneau, 627 D.K., Liebman, M., Polley, H.W., Quijas, S.J.J.o.E., 2017. Benefits of increasing plant 628 diversity in sustainable agroecosystems. J. Ecol. 105, 871-879.

629 Iverson, A.L., Marín, L.E., Ennis, K.K., Gonthier, D.J., Connor-Barrie, B.T., Remfert, J.L., 630 Cardinale, B.J., Perfecto, I., 2014. Do polycultures promote win-wins or trade-offs in 631 agricultural ecosystem services? A meta-analysis. J. Appl. Ecol. 51, 1593-1602.

632 Kim, K.H., Kabir, E., Jahan, S.A., 2017. Exposure to pesticides and the associated human 633 health effects. Sci. Total Environ. 575, 525-535. 
634 Klaa, K., Mill, P., Incoll, L., 2005. Distribution of small mammals in a silvoarable agroforestry

635 system in Northern England. Agrofor. Syst. 63, 101-110.

636 Kovács-Hostyánszki, A., Espíndola, A., Vanbergen, A.J., Settele, J., Kremen, C., Dicks, L.V., 637 2017. Ecological intensification to mitigate impacts of conventional intensive land use on 638 pollinators and pollination. Ecol. Lett. 20, 673-689.

639 Kranz, A.J., Wolz, K.J., Miller, J.R., 2018. Effects of shrub crop interplanting on apple pest 640 ecology in a temperate agroforestry system. Agrofor. Syst. https://doi.org/10.1007/s10457641 018-0224-8.

642 Kunz, T.H., Braun de Torrez, E., Bauer, D., Lobova, T., Fleming, T.H., 2011. Ecosystem 643 services provided by bats. Ann. N. Y. Acad. Sci. 1223, 1-38.

644 Lajeunesse, M.J., 2013. Recovering missing or partial data from studies: a survey of 645 conversions and imputations for meta-analysis, in: Koricheva, J., Gurevitch, J., Mengersen, 646 K. (Eds.), Handbook of meta-analysis in ecology and evolution. Princeton University Press, 647 Princeton, pp. 195-206.

648 Landis, D.A., Wratten, S.D., Gurr, G.M., 2000. Habitat management to conserve natural 649 enemies of arthropod pests in agriculture. Annu. Rev. Entomol. 45, 175-201.

650 Letourneau, D.K., Armbrecht, I., Rivera, B.S., Lerma, J.M., Carmona, E.J., Daza, M.C., 651 Escobar, S., Galindo, V., Gutiérrez, C., López, S.D., 2011. Does plant diversity benefit 652 agroecosystems? A synthetic review. Ecol. Appl. 21, 9-21.

653 Lewis, T., 1969. The distribution of flying insects near a low hedgerow. J. Appl. Ecol. 6, 443654452.

655 Marshall, E., 2004. Agricultural landscapes: field margin habitats and their interaction with

656 crop production. J. Crop Improv. 12, 365-404.

657 Martin, E.A., Reineking, B., Seo, B., Steffan-Dewenter, I., 2013. Natural enemy interactions 658 constrain pest control in complex agricultural landscapes. Proc. Natl. Acad. Sci. USA 110, $659 \quad 5534-5539$.

660 Matthews, S., Pease, S., Gordon, A., Williams, P., 1993. Landowner perceptions and the 661 adoption of agroforestry practices in southern Ontario, Canada. Agrofor. Syst. 21, 159-168.

662 Melbourne, B.A., 1999. Bias in the effect of habitat structure on pitfall traps: an experimental 663 evaluation. Aust. J. Ecol. 24, 228-239.

664 Meziere, D., Boinot, S., de Waal, L., Cadet, E., Fried, G., 2016. Arable weeds in alley 665 cropping agroforestry systems - results of a first year survey, 3rd European Agroforestry 666 Conference, 23-25 May 2016 Montpellier SupAgro, France, pp. 66-69.

667 Moher, D., Liberati, A., Tetzlaff, J., Altman, D.G., 2009. Preferred reporting items for 668 systematic reviews and meta-analyses: the PRISMA statement. Ann. Intern. Med. 151, 264669269.

670 Morandin, L., Long, R., Kremen, C., 2016. Pest control and pollination cost-benefit analysis 671 of hedgerow restoration in a simplified agricultural landscape. J. Econ. Entomol. 109, 10206721027.

673 Morandin, L.A., Kremen, C., 2013. Hedgerow restoration promotes pollinator populations 674 and exports native bees to adjacent fields. Ecol. Appl. 23, 829-839.

675 Morandin, L.A., Long, R.F., Kremen, C., 2014. Hedgerows enhance beneficial insects on 
adjacent tomato fields in an intensive agricultural landscape. Agric., Ecosyst. Environ. 189, 164-170.

Muhammad, N., Compton, S., Incoll, L., Akram, W., Lee, J.-J., 2005. Interaction of English grain aphid, Sitobion avenae (F.) and their natural enemies to an agro-forestry environment. J. Asia-Pacif. Entomol. 8, 175-183.

Murphy, B.C., Rosenheim, J.A., Dowell, R.V., Granett, J., 1998. Habitat diversification tactic for improving biological control: parasitism of the western grape leafhopper. Entomol. Exp. Appl. 87, 225-235.

Naeem, M., Compton, S., 2000. Population dynamics of filbert aphid, Myzocallis coryli (Goetze) on hazel bushes to an agroforestry system. Pakistan J. Biol. Sc. 3, 306-308.

Naeem, M., Compton, S., Incoll, L., Wright, C., Corry, D., 1997. Responses of aphids to a silvoarable agroforestry landscape. Agrofor. Forum 8, 18-20.

Naeem, M., Compton, S., Phillips, D., Incoll, L., 1994. Factors influencing aphids and their parasitoids in a silvoarable agroforestry system. Agrofor. Forum 5, 20-23.

Neumann, P., Carreck, N.L., 2010. Honey bee colony losses. J. Apic. Res. 49, 1-6.

Newman, S., Pilbeam, D., Briggs, S., 2018. Agroforestry in the UK, in: Gordon, A., Newman, S., Coleman, B. (Eds.), Temperate Agroforestry Systems, 2nd ed. CABI, Wallingford, UK, pp. $72-97$.

Newman, S.M., Gordon, A., 2018. Temperate agroforetry: key elements, current limits and opportunities for the future, in: Gordon, A.M., Newman, S.M., Coleman, B. (Eds.), Temperate Agroforestry Systems, 2nd ed. CABI, Wallingford, UK, pp. 274-298.

Nicholls, C.I., Altieri, M.A., 2013. Plant biodiversity enhances bees and other insect pollinators in agroecosystems. A review. Agron. Sustain. Dev. 33, 257-274.

Öberg, S., Mayr, S., Dauber, J., 2008. Landscape effects on recolonisation patterns of spiders in arable fields. Agric., Ecosyst. Environ. 123, 211-218.

Ondina, P., Hermida, J., Outeiro, A., Mato, S., 2004. Relationships between terrestrial gastropod distribution and soil properties in Galicia (NW Spain). Appl. Soil Ecol. 26, 1-9.

Peng, R., Incoll, L., Sutton, S., Wright, C., Chadwick, A., 1993. Diversity of airborne arthropods in a silvoarable agroforestry system. J. Appl. Ecol. 30, 551-562.

Peng, R., Sutton, S., 1996. The activity and diversity of ground arthropods in an agroforestry system. Proceedings of the NZ Plant Protection Conference, 309-313.

Pfannenstiel, R., Unruh, T., Brunner, J., 2010. Overwintering hosts for the exotic leafroller parasitoid, Colpoclypeus florus: Implications for habitat manipulation to augment biological control of leafrollers in pome fruits. J. Insect Sci. 10, 1-13.

Phillips, D., Griffiths, J., Naeem, M., Compton, S., Incoll, L., 1994. Responses of crop pests and their natural enemies to an agroforestry environment. Agrofor. Forum 5, 14-20.

Power, A.G., 2010. Ecosystem services and agriculture: tradeoffs and synergies. Philos. Trans. R. Soc. Lond., Ser. B: Biol. Sci. 365, 2959-2971.

Prasad, R., Snyder, W., 2006. Polyphagy complicates conservation biological control that targets generalist predators. J. Appl. Ecol. 43, 343-352. 
716 Pumariño, L., Sileshi, G.W., Gripenberg, S., Kaartinen, R., Barrios, E., Muchane, M.N.,

717 Midega, C., Jonsson, M., 2015. Effects of agroforestry on pest, disease and weed control: A

718 meta-analysis. Basic Appl. Ecol. 16, 573-582.

719 Pywell, R., James, K., Herbert, I., Meek, W., Carvell, C., Bell, D., Sparks, T., 2005.

720 Determinants of overwintering habitat quality for beetles and spiders on arable farmland.

721 Biol. Conserv. 123, 79-90.

722 R Core Team, 2018. R: A language and environment for statistical computing. R Foundation

723 for Statistical Computing, Vienna, Austria.

724 Rekany, N., 2015. Patterns in the Spatial Distribution of Invertebrates Providing Ecosystem

725 Services in Organic Agroforestry Systems. PhD thesis. University of Reading, UK.

727 Roger-Estrade, J., Anger, C., Bertrand, M., Richard, G., 2010. Tillage and soil ecology:

728 partners for sustainable agriculture. Soil Tillage Res. 111, 33-40.

729 Root, R.B., 1973. Organization of a plant-arthropod association in simple and diverse

730 habitats: the fauna of collards (Brassica oleracea). Ecol. Monogr. 43, 95-124.

731 Senior, A.M., Grueber, C.E., Kamiya, T., Lagisz, M., O'dwyer, K., Santos, E.S., Nakagawa,

732 S., 2016. Heterogeneity in ecological and evolutionary meta-analyses: its magnitude and

733 implications. Ecology 97, 3293-3299.

734 Sharman, J., 2015. The Impact of Organic Silvoarable Farming on Ground Beetle

735 Populations and Implications for Biological Control. MSc thesis. Nottingham Trent University, 736 UK.

737 Smith, J., Girling, R., Wolfe, M., Pearce, B., 2014. Agroforestry: Integrating apple and arable

738 production as an approach to reducing copper use in organic and low-input apple

739 production, in: McCracken, K. (Ed.), Agriculture and the Environment X: Deliverying Multiple

740 Benefits from our Land: Sustainable Development in Practice. SRUC, Edingburgh, Scotland,

741 pp. 278-284.

742 Smith, J., Pearce, B.D., Wolfe, M.S., 2012. A European perspective for developing modern

743 multifunctional agroforestry systems for sustainable intensification. Renew. Agric. Food Syst.

744 27, 323-332.

745

746

747

748

749

750

751

752

753

754

755

756

757
Smith, J., Pearce, B.D., Wolfe, M.S., 2013. Reconciling productivity with protection of the environment: Is temperate agroforestry the answer? Renew. Agric. Food Syst. 28, 80-92.

Smith, J., Wolfe, M., Crossland, M., 2016. Silvoarable agroforestry: an alternative approach to apple production?, 12th European International Farming Systems Association Symposium 'Social and technological transformation of farming systems: Diverging and converging pathways'. Harper Adams, UK, pp. 12-15.

Smits, N., Dupraz, C., Dufour, L., 2012. Unexpected lack of influence of tree rows on the dynamics of wheat aphids and their natural enemies in a temperate agroforestry system. Agrofor. Syst. 85, 153-164.

Sparks, T.C., Nauen, R., 2015. IRAC: Mode of action classification and insecticide resistance management. Pestic. Biochem. Physiol. 121, 122-128.

Stamps, W., Linit, M., 1997. Plant diversity and arthropod communities: implications for temperate agroforestry. Agrofor. Syst. 39, 73. 
Stamps, W., Linit, M., 1999. The problem of experimental design in temperate agroforestry.

759 Agrofor. Syst. 44, 187-196.

760 Stamps, W., McGraw, R., Godsey, L., Woods, T., 2009a. The ecology and economics of insect pest management in nut tree alley cropping systems in the Midwestern United States. Agric., Ecosyst. Environ. 131, 4-8.

Stamps, W.T., Nelson, E.A., Linit, M.J., 2009b. Survey of Diversity and Abundance of Ground-dwelling Arthropods in a Black Walnut-forage Alley-cropped System in the Midwestern United States. J. Kans. Entomol. Soc. 82, 46-62.

Stamps, W.T., Woods, T.W., Linit, M.J., Garrett, H.E., 2002. Arthropod diversity in alley cropped black walnut (Juglans nigra L.) stands in eastern Missouri, USA. Agrofor. Syst. 56, 167-175.

Straub, C.S., Finke, D.L., Snyder, W.E., 2008. Are the conservation of natural enemy biodiversity and biological control compatible goals? Biol. Control 45, 225-237.

The Woodland Trust, 2018. Agroforestry in England: benefits, barriers and opportunities.

772 The Woodland Trust Policy Paper.

773 Thies, C., Haenke, S., Scherber, C., Bengtsson, J., Bommarco, R., Clement, L.W.,

774 Ceryngier, P., Dennis, C., Emmerson, M., Gagic, V., 2011. The relationship between agricultural intensification and biological control: experimental tests across Europe. Ecol. Appl. 21, 2187-2196.

777 Thies, C., Roschewitz, I., Tscharntke, T., 2005. The landscape context of cereal aphid778 parasitoid interactions. Proc. R. Soc. Lond., Ser. B: Biol. Sci. 272, 203-210.

779 Thomas, C., Brown, N., Kendall, D., 2006. Carabid movement and vegetation density: 780 Implications for interpreting pitfall trap data from split-field trials. Agric., Ecosyst. Environ. 781 113, 51-61.

782 Tilman, D., Balzer, C., Hill, J., Befort, B.L., 2011. Global food demand and the sustainable intensification of agriculture. Proc. Natl. Acad. Sci. USA 108, 20260-20264.

Torralba, M., Fagerholm, N., Burgess, P.J., Moreno, G., Plieninger, T., 2016. Do European agroforestry systems enhance biodiversity and ecosystem services? A meta-analysis. Agric., Ecosyst. Environ. 230, 150-161.

Tscharntke, T., Klein, A.M., Kruess, A., Steffan-Dewenter, I., Thies, C., 2005. Landscape perspectives on agricultural intensification and biodiversity-ecosystem service management. Ecol. Lett. 8, 857-874.

Tschumi, M., Albrecht, M., Entling, M.H., Jacot, K., 2015. High effectiveness of tailored flower strips in reducing pests and crop plant damage. Proc. R. Soc. Lond., Ser. B: Biol. Sci. 282, 20151369.

793 Tsonkova, P., Böhm, C., Quinkenstein, A., Freese, D., 2012. Ecological benefits provided by 794 alley cropping systems for production of woody biomass in the temperate region: a review.

795 Agrofor. Syst. 85, 133-152.

Varah, A., 2015. Can agroforestry reconcile conflicting demands for productivity, biodiversity conservation and delivery of ecosystem services? PhD thesis. University of Reading.

798 Varah, A., Jones, H., Smith, J., Potts, S.G., 2013. Enhanced biodiversity and pollination in 799 UK agroforestry systems. J. Sci. Food Agric. 93, 2073-2075. 
800 Varchola, J.M., Dunn, J.P., 2001. Influence of hedgerow and grassy field borders on ground

801 beetle (Coleoptera: Carabidae) activity in fields of corn. Agric., Ecosyst. Environ. 83, 153-

802163.

803 Viechtbauer, W., 2010. Conducting meta-analyses in R with the metafor package. J. Stat.

804 Softw. 36, 1-48.

805 Whelan, C.J., Wenny, D.G., Marquis, R.J., 2008. Ecosystem services provided by birds.

806 Ann. N. Y. Acad. Sci. 1134, 25-60.

807 Williams, P., Koblents, H., Gordon, A., 1995. Bird use of an intercropped corn and old field in

808 Southern Ontario, Canada, in: Ehrenreich, J., Ehrenreich, D. (Eds.), Proceeding of the

809 Fourth Annual North American Agroforestry Conference. University of Idaho, Boise, Idaho,

810 pp. 23-28.

811 Winter, S., Bauer, T., Strauss, P., Kratschmer, S., Paredes, D., Popescu, D., Landa, B.,

812 Guzmán, G., Gómez, J.A., Guernion, M., 2018. Effects of vegetation management intensity

813 on biodiversity and ecosystem services in vineyards: a meta-analysis. J. Appl. Ecol.

814 https://doi.org/10.1111/1365-2664.13124

815 Woodcock, B., Bullock, J., McCracken, M., Chapman, R., Ball, S., Edwards, M.,

816 Nowakowski, M., Pywell, R., 2016. Spill-over of pest control and pollination services into

817 arable crops. Agric., Ecosyst. Environ. 231, 15-23.

818 Wright, C., 1994. The distribution and abundance of small mammals in a silvoarable

819 agroforestry system. Agrofor. Forum 5, 26-28.

820 